\title{
Is planting trees good or bad?
}

\author{
Vladan Ivetić, Jovana Devetaković, and Ivona Kerkez Janković \\ Faculty of Forestry, University of Belgarde, Kneza Višeslava 1, 11030 Belgrade, Republic of Serbia
}

\begin{abstract}
Planting trees is popular, widely accepted and supported, resulting with many initiatives and commitments around the globe. At the same time, planting trees is questioned more and more and receive a lot of criticism. In this paper we consider the arguments of both sides and discuss them using a scientific evidence. Determination of restoration opportunities and restoration needs requires more intention to existing ecosystems and their use. Commitments and expectations need to be realistic to maintain constant support based on real results. Planting trees is not the best solution for carbon storage, but it is one of the best solutions available at this moment. Even if reduce anthropogenic $\mathrm{CO} 2$ emission to zero, we will need to plant trees. Planting trees can have both negative and positive effect on water availability and socio-economy, depending on restoration practice applied. Planting trees is definitely good, if it is done at appropriate site and with appropriate tree species and if it is based on proper planning and realistic expectations.
\end{abstract}

\section{Introduction}

In past decades most countries worldwide have suffered forest loss or degradation due to changes of land use. This trend is mainly present in the tropics, where rates of forest loss between 2010 and 2030 are expected to be highest, but also several temperate and boreal regions are undergoing considerable degradation, even though overall forest cover is not significantly changing (WWF, 2015). Tree planting is the main tool in many international processes aiming to numerous restoration targets and objectives, yet constantly questioned and controversial. Tree planting results with planted forests which definition changes over the time, with changes in purpose of data collection and with changes in management goal (as reviewed by Ivetić 2019a). Comparing the biodiversity, regeneration characteristics, ecosystem functions and services provided, the difference between planted and naturally regenerated forest diminish with time (Baral et al. 2016), making a tree planting as a suitable tool for forest restoration. Planted forest make up 7 percent of the world's forest area and contribute over 40 percent of the global industrial wood and fibre supply (FAO, 2010). Depending on how they are established and managed, planted forests can provide numerous benefits or can have a negative impact on environment and society (FAO 2010, Batra and Pirard 2015, Ivetić 2019a). One of the main problems is that many planted forests have limitations in that they cannot supply the broad range of forest goods and services that society often requires (Laestadius et al., 2011). However, not all tree planting is the same and although often considered equal, a distinction should be made between reforestation and afforestation (Ivetić 2019b). The long-term outcomes of new forest established by 
planting strongly depends on way of establishment and a management goal. Despite the negative effects, reforestation, afforestation and restoration of forest landscapes can also have a positive effects on functionality and productivity of degraded lands and forests, boost food production and resilience of agricultural landscapes, also size up the supply of clean water, reduce erosion and provide wildlife habitat and mitigate climate change by sequestering carbon (Laestadius et al., 2011).Ambitious and large, sometimes gigantic initiatives and programs of forest restoration, forest landscape restoration, afforestation or simple tree planting has been launched worldwide in recent decades. Reasonably, this raises many questions and produce doubts. In both scientific community and public there are opposite opinions of those who promote and those who criticize tree planting. In this paper we consider the arguments of both sides and discuss them using a scientific evidence. This paper does not discuss different restoration approaches and definitions, but rather uses terms as they have been used in references used.

\section{Material and methods}

First, we searched on the social media and other online sources to identify the most usual critics on tree planting. These were divided in several subsections presented in Results and Discussion section. Then we made a primary search on the WoS, Scopus, and Google Scholar databases, looking for the scientific evidence on previously defined topics. Finally, we confronted the arguments against with arguments for tree planting and discussed them with support of scientific evidence.

\section{Restoration opportunities and restoration needs}

Two most influential and most criticized sources related to restoration opportunities are Atlas of Forest and Landscape Restoration Opportunities (https://www.wri.org/data/atlasforest-and-landscape-restoration-opportunities) published by the World Resources Institute (WRI) and the report published in Science (Bastin et al. 2019), both offering the global maps with area suitable for restoration. The Atlas of Forest and Landscape Restoration Opportunities recognize more than two billion $\left(2 \cdot 10^{9}\right)$ hectares worldwide offer opportunities for restoration (an area larger than South America), mostly in tropical and temperate areas. Specifically, 1,5 billion hectares best-suited for mosaic restoration; 0,5 billion hectares suitable for wide-scale restoration of closed forests; and 0,2 billion hectares of unpopulated lands, mainly in the far northern boreal forests, that have been degraded by fire, but difficult to restore. Bastin et al. (2019) have founded room for an extra 0.9 billion hectares of canopy cover (in addition to already existing trees and agricultural and urban areas).

Both received a lot of criticism to overestimate the amount of deforested and degraded forest land that is suitable for reforestation. For example, Veldman et al. (2015) founded that The Atlas of Forest and Landscape Restoration Opportunities misidentified 0,9 billion of hectares of ancient grassy biomes as suitable for forest restoration. More recently, Bond et al. (2019) reported that in Africa, 0,1 billion hectares, mostly of grassy biomes, have been wrongly targeted for restoration by 2030 , due to the erroneous assumption that these biomes are deforested and degraded. In many temperate countries, forest degradation is still occurring through replacement of native forests with plantations of commercial species and because of increased fire, pollution, invasive pests, poor management and over-exploitation (WWF, 2015).

Producing of precise map at a global scale is challenging and not necessarily successful. Although these critics are justified, maps like these are useful in recognizing the needs and 
opportunities for restoration. In any way, restoration will take place at local or regional level, the levels on which a decision on what should be restored and how, needs to be made. The real need for forest restoration (or not) is best to determine at landscape and local level. The next step is to determine the restoration target, to restore previous forest state or to restore forest ecosystem and socio-economic functions. The decision-making process for forest landscape restoration needs to recognize three important details (Stanturf and Mansourian 2020): 1) degraded areas are not necessarily uninhabited, 2) forest landscape restoration is not only about increasing forest cover/area but also about restoration of existing forests degraded by various reasons, and 3) the drivers of deforestation and degradation, must be addressed. Forest restoration at any level is not a straightforward to planting trees for increase of forest area, and when determining the restoration needs the past references, the present state and use of land, as well as the future predictions needs to be considered.

\section{Commitments, expectations, and reality}

Despite broad political support and enthusiasm, forest landscape restoration remains heavily underutilized in practice (Reinecke and Blum 2018). It seems that when commitments and high expectations meets reality, many programs fails to meet their initial targets, at least in the area and planted tree numbers.

For example, in April 2014, The Government of Kenya, the Kenya Red Cross Society, and the International Federation of Red Cross and Red Crescent Societies (IFRC) have signed a tripartite agreement to jointly undertake the Sustainable Environment and Restoration Programme (SERP) aimed at achieving the $10 \%$ threshold that will turn the tide against deforestation and its effects. The Kenya Red Cross Society has committed to support these initiatives by planting 2.5 billion trees and shrubs by 2018 (https://www.ifrc.org/fr/nouvelles/nouvelles/africa/kenya/greening-kenya-to-address-

environmental-sustainability-and-climate-change--65690/). Again, in December 2018 UN Environment joined the government of Kenya for the launch of 'Greening Kenya Campaign', as a part of Kenya's aim to plant 1.8 billion trees and achieve more than $10 \%$ forest cover in the country by 2022 . Yet, Kenya's government representatives pledged to provide only 50 million of the annual 500 million target tree seedlings (https://www.unep.org/news-and-stories/press-release/un-environment-joins-campaign-

green-kenya). It seems that the original program launched in 2014 failed to reach $10 \%$ of forest cover until 2018, leading to launch of new campaign in 2018. The difference in targeted number of planted trees indicate 0,7 billion of trees planted during the first program (although this difference can be due to other reasons as well). The good thing is that commitment is still there, but to avoid a risk of losing enthusiasm and support, targets and goals set at the beginning must not be overestimated in both number of planted trees and number of years.

Despite a "tremendous success of the Bonn Challenge in its first nine years" and a "set [of] such a tremendous ball rolling" in the report Bonn Challenge (2020) does not offer any empirical data on area restored globally, only pledges and commitments. The lack of reported results put doubts on this ambitious initiative launched in 2011 to bring 150 million hectares of degraded and deforested landscapes into restoration by 2020 and 350 million hectares by 2030, globally. Despite report that the Challenge surpassed the 150 million-hectare milestone for pledges in 2017, pledges and commitments are not the same as the restored areas. Again, it seems that at very beginning the numbers (of years and planted trees) are set to impress the public, not to meet the reality.

On the other side, more than 350 million trees were planted in 12 hours at the beginning of August 2019 in Ethiopia, as a part of the Green Legacy Initiative 
(https://www.unep.org/news-and-stories/story/ethiopia-plants-over-350-million-trees-daysetting-new-world-record). If the best appropriate knowledge and practices were applied this is an excellent success. This information sounds promising for global restoration efforts but having on mind a logistical challenge for such a huge action, brings many questions related to the proper species to site matching, seedling quality, origin of planting material. These issues directly affect the short-term and a long-term success of planting and should never be neglected. Maybe the better approach was to plant less in a longer period of time, but to build a success from the beginning.

Big-scale initiatives have transformative potential because of their scope and backing (Menz et al 2013), but also they require technology and knowledge capacity to successfully deliver restoration (Merritt et al. 2011), which must reach the greatest value for money, as far as socioeconomic and biodiversity conservation outcomes, while avoiding costly and simplistic plantings (Hobbs, 2007).

To avoid negative effects of restoration, Menz et al. (2013) proposed four-point plan to ensure that restoration sustains and enhances ecological values, based both socioeconomic and science-practice interface. Detailed restoration plans, which involve multiple stakeholders, should be used to avoid negative effects of restoration processes, such as reported in China's Great Green Wall and Grain for Green programs (Xi, 2011). To guide more effective restoration practice one of the main problems is the lack of information on successes and failures in landscape-scale restoration projects (Brudvig, 2011), so more attention should be paid to this problem in order to make a final conclusion about big-scale tree planting.

\section{Capability of trees to store carbon}

The forests capability to store carbon is undoubtful. A total forest sink is estimated to $2.4 \pm$ 0.4 petagrams of carbon per year $\left(\mathrm{Pg} \mathrm{C}\right.$ year $\left.^{-1}\right)$ globally (Pan et al. 2011). Yet, the capability of trees planted in large restoration programs is questioned.

As a reply to a huge number of sarcastic comments on his announcement to donate $\$ 100 \mathrm{M}$ towards a prize for best carbon capture technology (https://www.xprize.org/prizes/elonmusk) stating that trees and planting trees are an obvious solutions already available, Elon Musk replied, "They are part of the solution, but require lots of fresh water \& land. We may need something that's ultra-large-scale industrial in 10 to 20 years." Yes. Maybe the planting trees is not the best possible solution, but if done properly it is the closest to nature, providing a wide range of environmental and socio-economic services. Well established forest ecosystems are sustainable and resilient to challenges related to climate change.

In previously mentioned paper, Bastin et al. (2019) reported that establishment of new 0,9 billion hectares of canopy cover that could store 205 gigatonnes (Gt) of carbon highlights global tree restoration as our most effective climate change solution to date. Later, due to several comments on their paper published in Science they corrected their statement in the abstract of their paper to "global tree restoration as one of the most effective carbon drawdown solutions to date". In their comment to this paper, Friedlingstein et al. (2019) stated that this is a strong overestimation of the potential of forest restoration to mitigate climate change, scientifically incorrect and dangerously misleading, and that global forest restoration can only temporarily delay future warming. Despite good comments, Friedlingstein et al. (2019) gives no credit to forest restoration in climate change mitigation and state that the "only long-term and sustainable way to stabilize the climate at any temperature target is to reduce anthropogenic $\mathrm{CO}_{2}$ emissions to zero". In their comment on the paper by Bastin et al. (2019), Veldman et al. (2019) stated that estimation of 205 gigatonnes of carbon stored by additional tree planting "is 
approximately five times too large. Even more, Lewis et al. (2019) commented that "allowing trees to grow where they once grew is largely merely replacing carbon that was previously lost through land-use change, and so does not address fossil fuel emissions" and that "sequestering $\sim 100 \mathrm{GtC}$ into new forests is equivalent to just 10 years of current emissions, which clearly shows that forest restoration is of lower importance than rapidly reducing fossil fuel emissions". Yet, Veldman et al. (2019) give some credit to ecological restoration and their potential to have a role in mitigating climate change, "if carefully implemented", but that obviously "it is no substitute for the fact that most fossil fuel emissions will need to stop". On the other side, Grainger et al. (2019) are in favour of planting trees on large areas. In their response, Bastin et al. (2019) truly stated that their "study does not preclude the urgent need to reduce greenhouse gas emissions from the combustion of fossil fuels, from deforestation and forest degradation" and that "There is no compromise or trade-off between the two." Finally, in their comment, Skidmore et al (2019) "conclude that the emerging global political myth of massive tree planting and restoration as a panacea for global warming requires an unrealistically large area" and that "Although tree planting should be welcomed, curbing emissions appears to be the key, albeit politically challenging, action."

Growth of forest biomass carbon sink will rise under the climate change, to some extent. In their study of North American forests, Zhu et al. (2018) founded that future biomass (in 2080s) will sequester no more than $22 \%$ more carbon compared to today's level. The increase in carbon sequestration by forest biomass under the climate change is not equal over the globe. Ellsworth et al. (2017) reported that elevated $\mathrm{CO}_{2}$ did not increase forest productivity on a low-phosphorus soil, as are the large part of tropic soils. Another constrain to the increase in forest productivity under the atmospheric carbon dioxide enrichment is availability of nitrogen, which is expected to decline as the result of stand development (Norby et al. 2010). Additionally, although the positive effect of atmospheric carbon dioxide enrichment to the productivity of young forests is well documented (Hättenschwiler et al. 1997, Isebrands et al. 2001), experiment in the mature forests (Jiang et al. 2020) showed that additional carbon uptake did not lead to increased carbon sequestration at the ecosystem level. Under the climate change, the future forest carbon sink will be constrained by the increased tree mortality leading to the decrease in carbon turnover time ( $\mathrm{Yu}$ et al. 2019) which can lead to dangerous carbon cycle feedback (Anderegg et al. 2020). As the carbon sink in intact African tropical forests has been stable for the three decades to 2015, it declines in Amazonian forests, largely due to a long-term increase in carbon losses from tree mortality in Amazonia (Hubau et al. 2020). In the boreal forest biome, the mortality of Siberian forests is reported to be increased greatly in recent decades (Kharuk et al. 2021). There is a clear trend in overall forest vulnerability in Europe, driven by climate warming and its decreasing effect on forest resilience to the disturbances (Forzieri et al. 2021). It is highly likely that tree mortality rates will continue to increase globally, while tree recruitment and growth will vary spatially and temporally (McDowell et al. 2020). Compared to natural forests, planted forests are less resilient, due to their simpler and often even-aged structure, narrow diversity, and high density, especially during establishment phase (Ivetić 2019a). On the other hand, planted forest can be established with aim to provide high genetic diversity (including proveniencing strategies and increasing parental population for seed collection, reviewed by Ivetić and Devetaković 2017) and offer resistance to climate change. Perhaps new forests planting is the only cure for the carbon released by dying forests affected by climate change. 


\section{Planting trees effect on water availability}

Water availability behind air temperature have great influence on vegetation, but also affect on human communities and their livelihood. Green water, a water that resides in the unsaturated soil layer and vegetation canopy is tightly linked to water security (Falkenmark et al. 2006) and plant production for about $60 \%$ of the global food supply (Ringersma et al. 2003/2). Deforestation have a great influence on water resources (Vorosmarty et al. 2015), so many stakeholders have a perception that reforesting or forest expansion will help mitigate water shortage problems (Calder, 2007). Planting trees cannot be observed separately from long-term sustainable land and water management and still the impact of planting is at best unclear (Andreassian, 2004; Calder, 2007; Ellison et al. 2012; Filoso et al. 2017). Opposite results can be found in available literature, from reductions in annual runoff (mostly in arid and former grassland or shrubland areas) to recovery of water provision functions and improvement of surface water yields in watersheds (Filoso et al. 2017).Afforestation in Andean highlands of Ecuador reduced the water yield by $50 \%$ (Buytaert et al. 2007). In a study on impacts of a large-scale afforestation on the water storage balance of Southeast Asia, Xiao and Xsiao (2019) planted forests results with more water shortages, less rainfall, and higher evapotranspiration rates, compared to natural forests. The authors suggest to the China's Government to change the focus from afforestation to promoting natural vegetation conservation practices. We can agree with this suggestion only partially, considering that studied area (Yunnan-Guizhou Plateau) was subjected to plantation forestry. The forest restoration and even afforestation does not necessarily need to be plantation. Appropriate species selection and their mixtures and planting (including direct seeding) in irregular patterns can bring new forest closer to the natural forests. Lu et al. (2018) has reported increase of ground water depth in arid and semiarid northern China caused by afforestation by species unsuitable for local environmental constraints, and with evapotranspiration that exceeds the regional precipitation. Selection of species in a dryland afforestation projects primarly to withstand aridity has resulted in planted forests that are drought-resistant yet harm the natural ecosystem and provide inadequate ecosystem services for humans (Reisman-Berman et al. 2019).

The study in Ireland showed that afforestation leads to a reduction in runoff up to $20 \%$, that recharge rates under forests can be reduced to one tenth that under grass or heathland, and that groundwater quality may be affected by enhanced acidification and nitrification (Allen and Chapman 2001). In a region where natural runoff is $30 \%$ of precipitation, it is likely that planting trees will reduce it to half and in a region where natural runoff is less than $10 \%$ of precipitation it will probably result in a complete loss of runoff (Farley et al. 2005).

Despite that forest restoration can reduce water yield in catchments (Filoso et al. 2017) and eventually increase water security risk (Brancalion et al. 2019), in tropical rainforest landscapes, restoration can contribute to mitigate water supply risks as consequence of the siltation, fluvial erosion, enhancement of rainfall infiltration, recharge of water table and aquifers, regulation of water supply distribution and enhancement of moisture recycling (Ellison et al. 2017).

One of the major components of water balance in terrestrial ecosystems is evapotranspiration (Chang, 2006) and since that is known that forests have relatively high evapotranspiration rates in comparison to most other land use and cover types (Calder, 1998), as a consequence of conversion of different land uses into forests, decreasing of water yields occurs (Filoso et al. 2017). Since evapotranspiration rates decrease with forest age (Van Dijk and Keenan, 2007), influence of forest restoration can turn in favorable for increasing water yields. 


\section{Socio-economic aspect of planting trees}

Tree plantations are reported to cause more poverty (Andersson et al. 2016) and to threat the basis of traditional rural livelihoods (Bleyer et al. 2016). In a worldwide systematic review, the most studies report negative socio-economic impacts of large-scale tree plantations (Malkamäki et al. 2018), although with possible benefits to accrue over time. The more recent review suggests that plantation forests are not inherently positive or negative for local livelihoods (van der Meer Simo 2020). A review focused on reforestation/restoration programs and policies shows that the effects of large-scale restoration initiatives have mixed socioeconomic effects on local livelihoods depending on of off-farm jobs, household characteristics, land productivity, land tenure, and markets for forest products and ecosystem services (Adams et al 2016).

Most of the forest landscapes in tropics are deforested for purpose of livestock breeding, large and small-scale agriculture, unsustainable logging, pulp plantations, fires, characoal and fueldwood production, mining infrastructure and production of hydroelectric power (WWF, 2015). Countries in tropical region are in majority developing countries with rising economies mostly based on agriculture and food sector, but also on exploitation of resources such as fossil fuels. According to data of World Bank (https://databank.worldbank.org/) this region experienced high economic growth from the mid-2000's, but also rise of $\mathrm{CO}_{2}$ emissions (metric tons per capita). Rising economies benefits from forest loss in terms of economic growth, but lose in terms of environmental degradation. Ignoring the key social (as well as natural) factors often leads to failure (Cao et al. 2014). A large-scale corporate tree plantations are expected to have a negative impact to local communities. On the other side, planting trees for forest landscape restoration that not only include but prioritizes local communities is expected to have a positive effect, by aligning objectives of climate mitigation, conservation, environmental justice, and sustainable development (Erbaugh et al. 2020). A recent study reported satisfactory and beneficial overall social impacts of large-scale afforestation program in Pakistan, with increase of social sustainability by $69 \%$ (Khan et al. 2019). In some areas, like Chinese Loess Plateau, afforestation had negative effect on environment, by deep soil desiccation, soil erosion, and environmental pollution, despite of increasing economic value of forests and some farmers' income due to establishing of non-native forests which are not well suited to controlling soil erosion unless a a protective ground herb cover is also present (Jiang et al. 2016).

Finding a balance between socio-economic and environmental benefits have the greatest role in planting tree success. Spatial and temporal variability in the complex socialecological contexts highlights the difficulty in using short-term responses to indicate longterm recovery, so if restoration aims to accomplish with a win-win agenda (both social and ecological benefits) it must be based in socioeconomic and legal dimensions (Meli et al. 2017).

\section{Conclusions}

Although the knowledge base for implementing large-scale forest and landscape restoration needs further development (Chazdon et al. 2017), planting trees in restoration programs is far away of simple putting of seedlings in a ground wherever you can. Forest landscape restoration consider number of concepts and approaches and recognize the need of involvement of socio-economic and environment context (Chazdon et al. 2017, Stanturf and Mansourian 2020, César et al. 2021), as well as climate change adaptation (Löf et al. 2019). "Implementing FLR requires balancing competing interests and differing priorities for livelihoods versus biodiversity while aligning local with national goals." (Stanturf 2021). 
The complexity of landscapes as socio-ecological systems can be a strength instead of a problem for forest landscape restoration if approached as incorporating a portfolio of diverse objectives and methods (Stanturf et al. 2019).

There have been many mistakes in past and ongoing tree planting programs. China, as the country with largest past and ongoing tree planting programs, offers many lessons that needs to be learned for the future afforestation and restoration efforts. The use of inappropriate species and an overemphasis on planting trees, in many cases caused environmental degradation, i.e., deterioration of soil ecosystems, decreased vegetation cover, and increased water shortages (Cao et al. 2011).

The improvement of forest restoration is a constant process and efforts are invested globally to make existing knowledge more available and to offer some new solutions. Recently, Di Sacco et al. (2021) published "Ten golden rules for reforestation to optimize carbon sequestration, biodiversity recovery and livelihood benefits". These rules addressing the most important issues related to forest restoration and their impact to the environment. There are two ongoing networks focused on climate aspects of forestry and forest restoration, one under the European Forestry Institute (EFI) - European Network on Climate-Smart Forestry (https://www.vbne.nl/klimaatslimbosennatuurbeheer/projecteneuropa) and one under the COST Association - Pan-European Network for Climate Adaptive Forest Restoration and Reforestation (http://www.pen-caforr.org/). Beside these examples there are many efforts and studies at national and regional levels aiming to improve the forest restoration.

Determination of restoration opportunities and restoration needs requires more intention to existing ecosystems and their use. Commitments and expectations need to be realistic to maintain constant support based on real results. Planting trees is not the best solution for carbon storage, but it is one of the best solutions available at this moment. Even if reduce anthropogenic $\mathrm{CO}_{2}$ emission to zero, we will need to plant trees. Planting trees can have both negative and positive effect on water availability and socio-economy, depending on restoration practice applied. Planting trees is definitely good, if it is done at appropriate site and with appropriate tree species and if it is based on proper planning and realistic expectations.

\section{References}

1. A. Allen, D. Chapman, Hydrogeol J., 9, 390 (2001)

2. A. Di Sacco, K. A. Hardwick, D. Blakesley, P. H. S. Brancalion, E. Breman, L. Cecilio Rebola, S. Chomba, K. Dixon, S. Elliott, G. Ruyonga, K. Shaw, P. Smith, R. J. Smith, A. Antonelli, Glob. Change Biol., 27, 1328 (2021)

3. A. I. Van Dijk, R. J. Keenan, For Ecol Manag., 251(1), 1 (2007)

4. A. K. Skidmore, T. Wang, K. de Bie, P. Pilesjö, Science, 366(6469), eaaz0111 (2019)

5. A. Malkamäki, D. D’Amato, N. J. Hogarth, M. Kanninen, R. Pirard, A. Toppinen, W. Zhou, Glob Environ Change, 53, 90 (2018)

6. A. van der Meer Simo, Forests, 11(11), 1162 (2020)

7. Bonn Challenge (2020) Report. Accessed on 14 June 2021 at https://www.bonnchallenge.org

8. C. Adams, S.T. Rodrigues, M. Calmonand, C. Kumar, Biotropica, 48, 731 (2016)

9. C. J. Vorosmarty, A. Y. Hoekstra, S. E. Bunn, D., Conway, J. Gupta, Science, 349(6247), 478 (2015)

10. D. Ellison, M. N. Futter, K. Bishop, Glob Chang Biol.,18(3), 806 (2012) 
11. D. Ellison, C. E. Morris, B. Locatelli, D. Sheil, J. Cohen, D. Murdiyarso, V. Gutierrez, M. Noordwijk, I. F. Creed, J. Pokorny, D. Gaveau, D. V. Spracklen, A. B. Tobella, U. Ilstedt, A. J. Teuling, S. G. Gebrehiwot, D. C. Sands, B. Muys, B. Verbist, E. Springgay, Y. Sugandi, C. A. Sullivan Glob Environ Change, 43, 51 (2017)

12. D. Ellsworth, I. Anderson, K. Crous, et al., Nature Clim Change, 7, 279 (2017)

13. D. J. Merritt, K. W. Dixon, Science, 332(6028), 424 (2011)

14. FAO Planted forests in sustainable forest management. A statement of principles, (2010) http://www.fao.org

15. G. Forzieri, M. Girardello, G. Ceccherini, J. Spinoni, L. Feyen, H. Hartmann, P. S. A. Beck, G. Camps-Valls, G. Chirici, A. Mauri, A. Cescatti, Nat Commun, 12, 1081 (2021)

16. H. Baral, M. R. Guariguata, R. J. Keenan, Ecosyst Servir, 22, 260 (2016)

17. I. R. Calder, Forest Ecol Manag., 251(1), 110 (2007)

18. I. R. Calder, Tree Physiol.,18(8-9), 625 (1998)

19. J. A. Stanturf, M. Kleine, S. Mansourian, J. Parrotta, P. Madsen, P. Kant, J. Burns, A. Bolte, Ann. For. Sci. 76(2), 50 (2019)

20. J. A. Stanturf, S. Mansourian, R. Soc. Open Sci. 7, 201218 (2020)

21. J. F. Bastin, Y. Finegold, C. Garcia, D. Mollicone, M. Rezende, D. Routh, C. M. Zohner, T. W. Crowther, Science, 365(6448), 76 (2019)

22. J. G. Isebrands, E. P. McDonald, E. Kruger, G. Hendrey, K. Percy, K. Pregitzer, et al., Environ. Pollut., 115(3), 359 (2001)

23. J. Ringersm, N. Satjes, D. Dent, ISRIC - World Soil Information, Wageningen, Report $2003 / 2(2003)$

24. J. T. Erbaugh, N. Pradhan, J. Adams, J. A. Oldekop, A. Agrawal, D. Brockington, R. Pritchard, A. Chhatre, Nat. Ecol. Evol., 4(11), 1472 (2020)

25. J. W. Veldman, G. E. Overbeck, D. Negreiros, G. Mahy, S. Le Stradic, G. W. Fernandes, G. Durigan, E. Buisson, F. E. Putz, W. J. Bond, BioScience, 65(10), 1011 (2015)

26. J. W. Veldman, J. C. Aleman, S. T. Alvarado, T. M. Anderson, S. Archibald, W. J. Bond, T. W. Boutton, N. Buchmann, E. Buisson, J. G. Canadell, M. de S. Dechoum, M. H. Diaz-Toribio, G. Durigan, J. J. Ewel, G. W. Fernandes, A. Fidelis, F. Fleischman, S. P. Good, D. M. Griffith, et. al., Science, 366(6463), eaay7976 (2019)

27. J. Xu, Nat. News, 477(7365), 371 (2011)

28. J.A. Stanturf, Restor Ecol, 29, e13349 (2021)

29. K. Andersson, D. Lawrence, J. Zavaleta, M. R. Guariguata, Environ. Manage., 57(1), 123 (2016)

30. K. Naveed, S. J. Syed, R.Tariq, Z. Muhammad, Y. Cao, H. Jun. Forests 10(8), 703 (2019)

31. K. Yu, W. K. Smith, A. T. Trugman, R. Condit, S. P. Hubbell, J. Sardans, C. Peng, K. Zhu, J. Peñuelas, M. Cailleret, T. Levanic, A. Gessler, M. Schaub, M. Ferretti, W. R. L. Anderegg, Proceedings of the National Academy of Sciences, 116(49), 24662 (2019)

32. K. Zhu, J. Zhang, S. Niu, et al., Nat Commun, 9, 2709 (2018)

33. K.A. Farley, E.G. Jobbágy, R. B. Jackson, Glob Chang Biol, 11, 1565 (2005)

34. L. A. Brudvig, Am. J. Bot, 98(3), 549 (2011) 
35. L. Laestadius, S. Maginnis, S. Minnemeyer, P. Potapov, C. Saint-Laurent, N. Sizer, Unasylva, 62(2), 238 (2011)

36. M. Bleyer, M. Kniivilä, P. Horne, A. Sitoe, M. P. Falcão, Land Use Policy, 51, 281 (2016)

37. M. Chang, Forest hydrology: An introduction to water and forests. 2nd ed. Boca Raton: CRC press, 24 (2006)

38. M. Falkenmark, J. Rockstrom, J. Water Resour. Plann. Manage., 132(3), 129 (2006)

39. M. H. Menz, K. W. Dixon, R. J. Hobbs, Science, 339(6119), 526 (2013)

40. M. Jiang, B. E. Medlyn, J. E. Drake, et al., Nature, 580, 227 (2020)

41. M. Löf, P. Madsen, M. Metslaid, J. Witzell, D. F. Jacobs, New Forests 50, 139 (2019)

42. N. G. McDowell, C. D. Allen, K. Anderson-Teixeira, B. H. Aukema, B. BondLamberty, L. Chini, J. S. Clark, M. Dietze, C. Grossiord, A. Hanbury-Brown, G. C. Hurtt, R. B. Jackson, D. J. Johnson, L. Kueppers, J. W. Lichstein, K. Ogle, B. Poulter, T. A. M. Pugh, R. Seidl, M. G. Turner, M. Uriarte, A. P. Walker, C. Xu, Science, 368(6494), eaaz9463.

43. O. Reisman-Berman, T. Keasar, N. Tel-Zur, Ann. For. Sci., 76, 114 (2019)

44. P. Batra, R. Pirard, CIFOR infobrief, 121 (2015)

45. P. Friedlingstein, M. Allen, J. G. Canadell, G. P. Peters, S. I. Seneviratne, Science, 366(6463), eaay8060 (2019)

46. P. H. S. Brancalion, A. Niamir, E. Broadbent, R. Crouzeilles, F. S. M. Barros, A. M. Almeyda Zambrano, A. Baccini, J. Aronson, S. Goetz, J. L. Reid, B. B. N. Strassburg, S. Wilson, R. L. Chazdon, Sci. Adv., 5, eaav3223 (2019)

47. P. Meli, F. F. Herrera, F. Melo, S. Pinto, N. Aguirre, K. Musálem, C. Minaverry, W. Ramírez, P. H. Brancalion, Restor. Ecol., 25(2), 156 (2017)

48. R. J. Hobbs, Aust. J. Bot., 55(3), 371 (2007)

49. R. J. Norby, J. M. Warren, C. M. Iversen, B. E. Medlyn, R. E. McMurtrie, Proceedings of the National Academy of Sciences, 107(45), 19368 (2010)

50. R. L. Chazdon, P. H. S. Brancalion, D. Lamb, L. Laestadius, M. Calmon, C. Kumar, Conserv. Lett., 10, 125 (2017)

51. R.G. César, L. Belei, C.G. Badari, R. A. G. Viani, V. Gutierrez, R. L. Chazdon, P. H. S. Brancalion, C. Morsello, Land, 10, 28 (2021)

52. S. Cao, L. Chen, D. Shankman, C. Wang, X. Wang, H. Zhang, Earth Sci. Rev., 104(4), 240 (2011)

53. S. Cao, H. Ma, W. Yuan, X. Wang, Biol. Conserv.,180, 270 (2014)

54. S. Filoso, M. O. Bezerra, K. C. Weiss, M. A. Palmer, PloS one, 12(8), e0183210 (2017)

55. S. Hättenschwiler, F. Miglietta, A. Raschi, C. Körner, Glob. Chan. Biol., 3(5), 463 (1997)

56. S. L. Lewis, E. T. A. Mitchard, C. Prentice, M. Maslin, B. Poulter, Science, 366(6463), eaaz0388 (2019)

57. S. Reinecke, M. Blum, Sustainability, 10(3), 613 (2018)

58. V. Andreassian, J Hydrol (Amst)., 291(1-2), 1 (2004)

59. V. I. Kharuk, S. T. Im, I. A. Petrov, M. L. Dvinskaya, A. S. Shushpanov, A. S. Golyukov, Glob. Ecol. Biogeogr., 30, 543 (2021) 
60. V. Ivetić, Planted Forests: Characterization and Sustainable Management. In: Leal Filho W., Azul A., Brandli L., Özuyar P., Wall T. (eds) Life on Land. Encyclopedia of the UN Sustainable Development Goals. Springer, Cham. Online ISBN 978-3-31971065-5 (2019)

61. V. Ivetić, Reforestation and Sustainable Development. In: Leal Filho W., Azul A., Brandli L., Özuyar P., Wall T. (eds) Life on Land. Encyclopedia of the UN Sustainable Development Goals. Springer, Cham. Online ISBN 978-3-319-71065-5 (2019)

62. W. Buytaert, V. Iñiguez, B. De. Bièvre, For. Eco. Manag., 251(1), 22 (2007)

63. W. Hubau, S. L. Lewis, O. L. Phillips, et al., Nature, 579, 80 (2020)

64. W. J. Bond, N. Stevens, G. F. Midgley, C. E. R. Lehmann, Trends Ecol. Evol., 34(11), 963 (2019)

65. W. Jiang, S. Yang, X. Yang, N. Gu, Quat. Int., 399, 165 (2016)

66. W. R. L. Anderegg, A. T. Trugman, G. Badgley, C. M. Anderson, A. Bartuska, P. Ciais, D. Cullenward, C. B. Field, J. Freeman, S. J. Goetz, J. A. Hicke, D. Huntzinger, R. B. Jackson, J. Nickerson, S. Pacala, J. T. Randerson, Science, 368(6497), eaaz7005 (2020)

67. WWF, Saving forests at risk, WWF living forests report: Chapter 5, Ed. Taylor R., WWF International, Avenue du Mont Blanc, 1196 Gland, Switzerland. ISBN 978-2940443-32-1 (2015) https://c402277.ssl.cf1.rackcdn.com

68. Y. Pan, R. A. Birdsey, J. Fang, R. Houghton, P. E. Kauppi, W. A. Kurz, O. L. Phillips, A. Shvidenko, S. L. Lewis, J. G. Canadell, P. Ciais, R. B. Jackson, S. W. Pacala, A. D. McGuire, S. Piao, A. Rautiainen, S. Sitch, D. Hayes, Science, 333(6045), 988 (2011) 